\title{
Study on Investment Value under Government Guarantee in PPP Project Based on OnlineSimulation
}

\author{
Runrun Dong \\ HeNan University of Technology \\ ZhengZhou, China \\ Email:1158049082@qq.com
}

\begin{abstract}
Regarding the options value of the civilian airport infrastructure, government guarantee of the civil airport industry can add to the project option value. The author considers there are three kinds of governmentguarantee, which include minimum government guarantee, bilateral government guarantee and restricted competition. The paper uses MATLAB to calculate the impact of government guarantee on project value by online simulation. A case of Hongqiao business jet base is studied in order to prove these threeoption models.
\end{abstract}

Keywords--Index Terms Government guarantee; Investment value; ATLAB; Online simulation; PPP project

\section{INTRODUCTION}

The greatest concern for the investors of airport infrastructure is to be able to achieve the expected economic benefits. According to the traditional decision method of cash flow, when the internal rate of return on an investment project is greater than the benchmark discount rate[1], policy makers should invest right away. However, cash flow in the actual operational period may be inconsistent with the forecasted cash flow. When the actual value is lower than the predicted value, the original decision might lead to errors. The investment may be difficult to recover or the recovery period will be extended from the view of the options. In addition to the value of the project that is based on the time value under traditional decision-making methods, the project also includes a flexible value from project management as well as the value of uncertain information (i.e., value of flexibility in management)[2]. The value of the project is the sum of the present value of cash inflows and the project flexibility value[3]. Traditional decision-making methods assume that the asset value of the investment projects will be reduced with the increased uncertainty. Also, real options theory states that uncertainty will increase the value of the project if managers can make effective business decision[4]. Investment in civilian airport infrastructure has a huge one-time investment and a long payback period. Accordingly, project uncertainty must be fully considered, including market uncertainty and the uncertainty of the construction costs.

\author{
Hairong Huang \\ HeNan University of Technology \\ ZhengZhou, China \\ Email:282437249.qq.com
}

\section{THEORETICAL ANALYSIS OF GOVERNMENT}

\section{GUARANTEE}

Govern ment guarantee refers to compensation promise which the government offers to the secured party, when the income of secured party is lower than the set security level. The secured party can be a private investor financial institution. As private investors provide public infrastructure projects, the important role of the government guarantee is paid more and more attention, which mainly includes the following reasons:

Firstly, government guarantee is the most widely guarantee way of private investors participating in the infrastructure construction. Reasonable government civilian guarantee is the key factor to promote the success of PPP model. In developing countries, imperfect political and economic system, low level of the government credit and the fluctuation of exchange rate are the main risk factors of successful PPP project, which wants to realize the PPP mode of the target and the original intention, funds and technical service for private investors in infrastructure projects, providing government guarantee has become an important means to reduce the project risks, which makes capital and technology of private investor effectively serve to the infrastructure. For example, government guarantee can reflect in stable interest rates, sound laws and regulations, stable political system and so on.

Secondly, the government guarantee can reduce the price of public infrastructure products, increases consumer usage so as to increase consumer surplus and promote the improvement of the social welfare. The government guarantee of PPP project mainly reduces the risk and ensure scertain income level of investors, transportation infrastructure project vehicle tolls, aircraft taking off and landing fees is the only source of income, the reasonable security of government can inhibit the potential risk of rising price to protect the interests of consumers. But because of the existence of information asymmetry between government and private investors, if government does not provide sufficient guarantee to stimulate the secured party to improve the service level, it will bring about low level of social welfare, and cannot achieve the expected goal of government scale. 
Thirdly, as the government guarantee will take effect only if the income of project is lower or higher than set security level, the guarantee does not actually produce immediate cash cost but an expected liability. In fact, when an investment is supplied with government guarantee, an expected liability represents a real debt. According to Lewis, the average cost of the guarantee can reaches to $1 / 3$ of guarantee amount.

Both developed and developing countries actively explore their own infrastructure construction plan. In order to further strengthen the capacity of infrastructure supply and make up long-term serious shortage situation of investing in the construction of infrastructure finance only by government funding and government loans, utilization of the government guarantee become more and more popular. The government guarantees means that the government must compensate to the secured party when the secured party's income is lower than the set guarantee and the secured party are either private investors or financial institutions.

TABLE I. COTENR OF GOVERNMENT 'SGUARANTEE

\begin{tabular}{|c|c|c|}
\hline Warranties & Form of Expression & $\begin{array}{c}\text { Existing } \\
\text { Term or } \\
\text { Condition }\end{array}$ \\
\hline $\begin{array}{l}\text { The minimum } \\
\text { income guarantee }\end{array}$ & $\begin{array}{l}\text { If the annual operating } \\
\text { income is less than the } \\
\text { income as agreed in the } \\
\text { contract, the government } \\
\text { provides subsidy for the } \\
\text { investors. }\end{array}$ & $\begin{array}{l}\text { During } \\
\text { franchise } \\
\text { period }\end{array}$ \\
\hline $\begin{array}{l}\text { The minimum } \\
\text { amount of traffic } \\
\text { security }\end{array}$ & $\begin{array}{l}\text { If the annual traffic volume } \\
\text { is greater than or equal to the } \\
\text { volume of traffic as agreed in } \\
\text { the contract, the government } \\
\text { does not provide any } \\
\text { subsidies; otherwise the } \\
\text { government makes up the } \\
\text { actual traffic volume to a } \\
\text { certain percentage. }\end{array}$ & $\begin{array}{l}\text { During } \\
\text { franchise } \\
\text { period }\end{array}$ \\
\hline $\begin{array}{l}\text { Guarantee of } \\
\text { investment } \\
\text { returns }\end{array}$ & $\begin{array}{l}\text { Determination of the rate of } \\
\text { return on investment rate } \\
\text { contract, if business income } \\
\text { exceeds the limit of rate of } \\
\text { maximum return, the } \\
\text { government and investors } \\
\text { share profit according to the } \\
\text { predetermined proportion.If } \\
\text { the business income is lower } \\
\text { than the rate of minimum } \\
\text { return limit, then the } \\
\text { government provides subsidy } \\
\text { for invest ors. }\end{array}$ & $\begin{array}{l}\text { During } \\
\text { franchise } \\
\text { period }\end{array}$ \\
\hline $\begin{array}{l}\text { Purchase } \\
\text { guarantee }\end{array}$ & $\begin{array}{l}\text { The government will ensure } \\
\text { to buy a certain number of } \\
\text { product prices from investors } \\
\text { each year. }\end{array}$ & $\begin{array}{l}\text { During } \\
\text { franchise } \\
\text { period }\end{array}$ \\
\hline $\begin{array}{l}\text { Preferential tax } \\
\text { guarantee }\end{array}$ & $\begin{array}{l}\text { The government provides all } \\
\text { aspects of preferential tax for } \\
\text { investors, including tariffs of } \\
\text { imported equipment, tax of } \\
\text { invest ors receive dividends, } \\
\text { and dividend withholding } \\
\text { tax. }\end{array}$ & $\begin{array}{l}\text { During } \\
\text { franchise } \\
\text { period }\end{array}$ \\
\hline $\begin{array}{l}\text { Foreign exchange } \\
\text { guarantee }\end{array}$ & $\begin{array}{l}\text { The government promises } \\
\text { that operating profits can be } \\
\text { convertible into foreign } \\
\text { currency. }\end{array}$ & $\begin{array}{l}\text { During or } \\
\text { after } \\
\text { franchise } \\
\text { period } \\
\end{array}$ \\
\hline
\end{tabular}

\begin{tabular}{|c|l|c|}
\hline $\begin{array}{c}\text { Guarantee of } \\
\text { restricting }\end{array}$ & $\begin{array}{l}\text { The government promises to } \\
\text { the PPP company that the } \\
\text { same project is no longer } \\
\text { approved at a certain time } \\
\text { and space. }\end{array}$ & $\begin{array}{c}\text { During } \\
\text { franchise } \\
\text { period }\end{array}$ \\
\hline The protection of & $\begin{array}{l}\text { The government should take } \\
\text { the corresponding measures } \\
\text { to protect secret information } \\
\text { and intellectual property } \\
\text { from free loss. }\end{array}$ & $\begin{array}{c}\text { During or } \\
\text { after } \\
\text { franchise } \\
\text { period }\end{array}$ \\
propertlectual rights
\end{tabular}

\section{THE METHOD OF GOVERNMENT GUARANTEE PRICING}

In order to attract private investors to invest in PPP projects, the government tends to give some as surance to enhance the confidence of their investment. Currently, the most popular form of government guarantees include: purchase guarantee, restriction of competition, exchange guarantee, the minimum income guarantee and so on (see Table 1). For example, the Malaysia government for the provides a minimu $\mathrm{m}$ income guarantee for item company which constructs North-South Highway, the government plays a positive role in promoting the successful operation of PPP projects. Zhang Xueqing [5] points out that in PPP projects, the government should undertake the risk of political and other macroeconomic environment, and should bear the losses caused by irresistible force and project delay. Irwin et al[6] divides the risk that government should bear into political risk, business risk, construction risk and interest rate risk. Gilberto[7] summarizes the main risk of the government should bear in BOT project into market risk, payment risk and legal risk.

There are three kinds of methods to set the price of government guarantee: (1) The method of historical experience. The level of guarantee is equal to the amount of guarantee multiplied by certain proportion, which is mainly based on the experience and judgment. The method is practical, but lack of convincing evidence.(2) The method of market value. This method assumes that the basic project of market value not only contains the value of non-governmental investment, but also includes the government guarantee value, the premise is the market prices fully reflect the market supply and demand, the value of government guarantee equals to the difference between the price of infrastructure project under government guarantee and the market price of project under no government guarantee.(3) The method of option pricing Option is a kind of right to take some action in the future, when there is uncertainty, option is valuable.As a kind of expected claim, guarantee has a basis of applying theory of option for its pricing.Merton [8]takes guarantee as put option in the field of guarantee pricing research, and uses the option theory to calculate the guarantee value. Jones [9] thinks the government guarantee can also be regarded as a put option, and uses the method of option pricing to calculate the value of government loan guarantee.

\section{CASE STUdIES}

In Shanghai, October 2006, Shanghai Airport Authority and Australia's Hawker Pacific Business Aviation Development Co., Ltd., which makes the Shanghai business jet base project, signed a memorandum 
of cooperation and entered into a substantive start-up phase. The total investment of the joint venture is 175 million yuan, and the registered capital is 120 million yuan.The Airport Group invested 61.2 million yuan, accounting for $51 \%$, and Hawke companies invested 58.8 million yuan, accounting for $49 \%$. According to the estimate of the feasibility study report, a one-time payment of all ground facilities, lease costs and $50 \%$ of the land lease costs, the part of the rent totaling to approximately 1.0255 billion; and additional $50 \%$ of the land lease fee costs(53 million yuan in 20 years), which totally accumulates to approximately 1 billion. The joint venture awarded Hawke the right to operate in Shanghai Airport and engage in the business jet terminal building and apron services. A one-time rental income equal to the total cost of the construction, and $5 \%$ of the revenue each year pays for the franchise fee. In the calculation process, a one-time rental of 1.0255 billion of the joint venture company is thought to be the investment of the project. The other $50 \%$ of the rental fee as operating costs are allocated to 20 years' payment. According to the traditional cash flow evaluation methods, long-term bonds yieldinga risk-free interest rate of $6.15 \%$ are made.An investment net present value (NPV) of Shanghai Hongqiao business jet base is 22.8293 million yuan. From the view of traditional investment decision-making theory, NPV> 0, the investment project can be launched, but the rate of return is similar to the risk-free rate. Therefore, for investors, this is not very attractive. Moreover, the operating cycle of the project is up to 21 years. For investment projects, there are many risk factors,but if investors take into account fluctuations of the PPP (Public-Private-Paternership) project cash flow, then the investment value of the project may not be so low. Here in, we re-evaluate the value of the project based on the method of Government guarantee pricing.

\section{EST ABLISHING THE OPTIONMODEL OF GOVERNMENT}

\section{GUARANTEE}

This section will take a certain proportion of measurement of aircraft taking off and landing as guarantee amount, this ratio is set to $m, Q_{t}^{E}$ represents prediction of official machine movements in yeart, $Q_{t}^{R}$ represents actual movements of official machine in year $t, Q_{t}^{G}$ represents guarantee movement of official machine in year $t, t=n+1, \ldots, T, Q_{t}^{C}$ represents the highest flights of the government guarantee(it is a certain proportion of measurement of aircraft taking off and

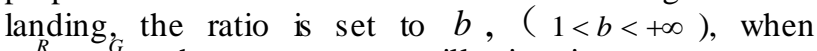
$Q_{t}{ }^{R}<Q_{t}$, the government will give item company a certain proportion of the difference between actual movements and guarantee movements, this ratio is set to $S$, when $Q_{t}{ }^{R}>Q_{t}{ }^{2}$, the government will obtain a certain

percentage of extraction of extra income, this percentage is set to $w$.

\section{A. The option value model under minimum government guarantee}

If actual move ment of aircraft taking off and landing is lower than $Q_{t}^{G}$, item company can execute put option, which received a subsidy of $\left(Q_{t}-Q_{t}^{R}\right) P_{t} \cdot s$,
$S F_{i}=\left\{\begin{array}{ll}0, & \text { if } Q_{t}^{R} \geq Q_{t}^{G} \\ \left(Q_{t}^{G}-Q_{t}^{R}\right) \cdot P_{t} \cdot s & \text { if } Q_{t}^{R} \leq Q_{t}^{G}\end{array}(1)\right.$

\section{B. The option value model under bilateral government}

\section{guarantee}

Bilateral government guarantee for company performs a double barrier option.Based on minimum guarantee of aircraft taking off and landing, the government takes measure to limit high profit which is not reasonable.The government sets a certain proportion as the highest aircraft movements based on the prediction of aircraft taking off and landing, when the aircraft movements in year $t$ is higher than the set level, the government extracts part of the extra revenue.

$$
S F_{i}=\left\{\begin{array}{lr}
\left(Q_{t}^{R}-Q_{t}^{G}\right) \cdot P_{t} \cdot s & \text { if } Q_{t}^{R} \leq Q_{t}^{G}, \\
0 & \text { if } Q_{t}^{G} \leq Q_{t}^{R} \leq Q_{t}^{C}, \\
\left(Q_{t}^{R}-Q_{t}^{C}\right) \cdot P_{t} \cdot w & \text { if } Q_{t}^{R} \geq Q_{t}^{C}
\end{array},\right.
$$

\section{The option value model under restricting}

\section{competition}

Restricted competition is more common in the civil airport industry, when aircraft movements are greater than a set value. The Govern ment has the right to build in the same geographical range as the second business jet base. When aircraft movements are greater than the highest limit, the second home business jet base has the right to start operations. Additionally, the original business jet base often maintains a competitive advantage in the operating period that is embodied in the mathematical model, which means additional revenue should be extracted by the government. This is shown in the following formula:

$S F_{i}=\left\{\begin{array}{ll}0, & \text { if } Q_{t}^{R} \leq Q_{t}^{C}, \\ \left(Q_{t}^{R}-Q_{t}^{C}\right) \cdot P_{t} \cdot w & \text { if } Q_{t}^{R} \geq Q_{t}^{C}\end{array}\right.$,

Here, report the impact of the restriction competition on project value under the initial aircraft movements, aircraft movement's growth rate and other factors based on the Charles (2006) model[11]. Investors have a call option. The benchmark rate of return is $7.15 \%$, according to the feasibility study report. The calculation steps are as follows: (1) Determine the probability distribution of the initial business jet movements, the probability distribution of the growth rate of aircraft movements and the probability distribution of the annualair craft movement's income. (2) Based on the above parameters, the distribution path of aircraft movements have been simulated in the period of the concession. (3) In each path, when the condition is triggered, the condition of call options is set by the government's guarantee. Additionally, the government revenue is calculated, and here calculate the government revenue on each path. (4) To simulate multiple paths, and calculate the statistical value of 
government revenue. The theoretical value of the initial jets taking off and landing have an important impact on the economic benefits of the official machine base. Although, estimating is difficult, make an estimate of initial movement of the business jet in feasibility report for numerical calculation (see Table 2). According to the 'feasibility study report of Shanghai business jet base, the growth rate of business jet movement changes along with time.

TABLE II. PROBABILIT Y DIST RIBUTION OF THE OFFICIAL MACHINES WITH INITIAL MOVEMENTS

\begin{tabular}{|c|c|c|c|c|}
\hline Variable & $\begin{array}{c}\text { Distributio } \\
\text { n }\end{array}$ & Mean & $\begin{array}{c}\text { Gowth } \\
\text { Rate }\end{array}$ & $\begin{array}{c}\text { Standard } \\
\text { De viatio } \\
\text { n }\end{array}$ \\
\hline $\begin{array}{c}\text { The initial } \\
\text { movements }\end{array}$ & $\begin{array}{c}\text { The log } \\
\text { normal } \\
\text { distribution }\end{array}$ & $\begin{array}{l}\text { movements } \\
\text { of the first } \\
\text { year }\end{array}$ & 0 & $14 \%$ \\
\hline
\end{tabular}

Due to the project construction and early operation time, which is an important stage for official machine development, in the first stage, the growth rate reached $15 \%$. After the year of 2017 , the construction of business jet projects goes into operation in China, although these bases are geographically far away from each other. However, they have a certain influence on the project, therefore, after the year of 2025, the growth rate will drop to $10 \%$, and the growth of official machine movements will go into a stable stage because of the project design capacity.

Based on prediction of the growth rate of official machine movements, during the operational period, the growth rate and the volatility of aircraft movements is calculated (see Table 3 ).

The jet base income cannot be directly calculated through the car goods flow as well as the air cargo station or highway project. The income of the official machine base is divided into three parts. Firstly, the income of FBO (Fixed Base Operator), in which the revenue of this part includes parking service, channel service, ground service and agency services .

\section{TABLE III. THE GROWTH OF BUSINESS JET MOVEMENTS}

\begin{tabular}{|c|c|c|}
\hline Operating years & mean & Standard deviation \\
\hline $2009-2016$ & $14 \%$ & $11.4 \%$ \\
\hline $2017-2024$ & $8 \%$ & $6.45 \%$ \\
\hline $2025-2029$ & $1 \%$ & $1.74 \%$ \\
\hline
\end{tabular}

All kinds of income from services can be calculated by a public frame time multiplied by the service rate. However, the volu me of four different business services is often different, and the most basic service is the stopping service and channel service. When the development of these two kinds of service becomes mature, it can drive the development of ground services and agency services. Secondly, the income of MBO (Maintenance Base Operator), the revenue and income of this part includes repair income, spare parts sales income, subcontracting income and warehouse management income. Thirdly, management and charter income, this can be divided into small, mediu m and large machine charters. The parameter calculated in Table 5 is based on parking services, in which other services can be regarded as the extension of the parking services and ancillary revenue services. During the operational period, the same number of parking services brings about different service incomes, which is due to the different stages of development. In general, in the initial stage of development, aircraft parking services brings about a low income. However, during the development of the later operational stages, due to the rich service content and improved quality, aircraft income will increase, which is brought about by parking service. To a certain extent, income caused by each aircraft is fixed at a certain level, but the operating costs will rise because of various factors (see Table 4).

TABLE IV. OFFICIALAIRCRAFT T AKINGOFF AND LANDING OF ANNUAL INCOME

\begin{tabular}{|c|c|c|c|}
\hline Year & $\begin{array}{c}\text { Official } \\
\text { Machine } \\
\text { Movement } \\
\text { s }\end{array}$ & $\begin{array}{l}\text { Annual } \\
\text { Total } \\
\text { Income } \\
\text { (yuan) }\end{array}$ & $\begin{array}{c}\text { The Average } \\
\text { Income } \\
\text { (million yuan) }\end{array}$ \\
\hline 2009 & 1200 & 240 & 0.2 \\
\hline 2010 & 1368 & 1131 & 0.8268 \\
\hline 2011 & 1559 & 1757 & 1.1267 \\
\hline 2012 & 1777 & 3097 & 1.7420 \\
\hline 2013 & 2026 & 4126 & 2.0358 \\
\hline 2014 & 2311 & 5179 & 2.2416 \\
\hline 2015 & 2633 & 6287 & 2.3869 \\
\hline 2016 & 3002 & 7239 & 2.4108 \\
\hline 2017 & 3243 & 7558 & 2.3306 \\
\hline 2018 & 3502 & 7810 & 2.2299 \\
\hline 2019 & 3782 & 8110 & 2.1440 \\
\hline 2020 & 4085 & 8169 & 1.9997 \\
\hline 2021 & 4412 & 8229 & 1.8561 \\
\hline 2022 & 4765 & 8290 & 1.7398 \\
\hline 2023 & 5146 & 8354 & 1.6234 \\
\hline 2024 & 5558 & 8217 & 1.4785 \\
\hline 2025 & 5613 & 8485 & 1.5116 \\
\hline 2026 & 5725 & 8555 & 1.4942 \\
\hline 2027 & 5782 & 8626 & 1.4917 \\
\hline 2028 & 5898 & 8700 & 1.4750 \\
\hline 2029 & 5958 & 8775 & 1.4729 \\
\hline
\end{tabular}

\section{THE RESULTS OF CALCULATION}

\section{A. The option value under minimum government}

\section{guarantee}

Fig. 1 is distribution diagram of expenditure of government subsidies (using MATLAB to simulate 1000 paths), when the set ratio of government guarantee is 0.75 , the lowest subsidies of government security to official machine movements is possibly an average of 2366700 yuan (see Table5), compared with the calculation of the net present value, the possible subsidies expenditure is smaller, project value of the investment value is 2519.6 (million). During the operation period, if the actual aircraft movements have large deviation with the benchmark of official machine movements, actual results will have great difference from the simulation results.In practice, there are many ways to achieve the function of government minimum guarantee, such as preferential tax can not only improve the attractiveness of the airport to investors, but also can reduce the risk of the civil airport during the operation of the project. 
B. The option value under bilateral government guarantee

As it is shown in Fig. 3 and Fig. 4, when the percentage of minimum government guarantee is 0.75 , subsidy coefficient is 0.3 , the maximu m restriction ratio is 1.3 , the percentage of extraction is 0.3 , under bilateral guarantee, the expected expenditure is an average of 2366700 yuan, the expected income of government is an average of 3720500 yuan. From the view option, through bilateral guarantee, the government obtains two kinds of real option, the put option value is 2366700 yuan, the call option value is 7440400 yuan, a difference of 5073700 yuan (see Table 6). It can be seen that under above ratio of guarantee and restriction, the beneficiary is government.

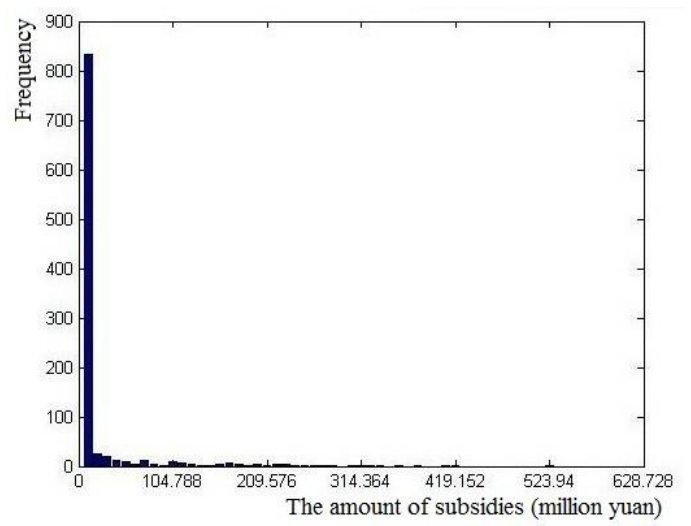

Figure 1. The amount of subsidies under minimum government guarantee

TABLE V. SIMULATION RESULT SOF SUBSIDY FROM GOVERNMENT UNDER MINIMUM SECURITY

\begin{tabular}{|c|c|c|c|}
\hline Statistics & $\begin{array}{c}\text { Simulation } \\
\text { Times }\end{array}$ & Mean & $\begin{array}{c}\text { Standard } \\
\text { Deviation }\end{array}$ \\
\hline Numerical & 1000 & 236.67 & 23085.51 \\
\hline
\end{tabular}

As is shown in Fig. 2, if other factors do not change, the higher is the proportion of minimum government guarantee, the more is possible govemment expenditure, there is a significant positive correlation between these two factors.

\section{The option value under restricting competition}

As is shown in Fig. 5, in the case of restricting competition, according to the government contract pumping ratio $(0.4)$ and governmentrestriction on competition ratio (1.3), the governmentrevenue is 9.2881 million yuan.If the government contractpumping

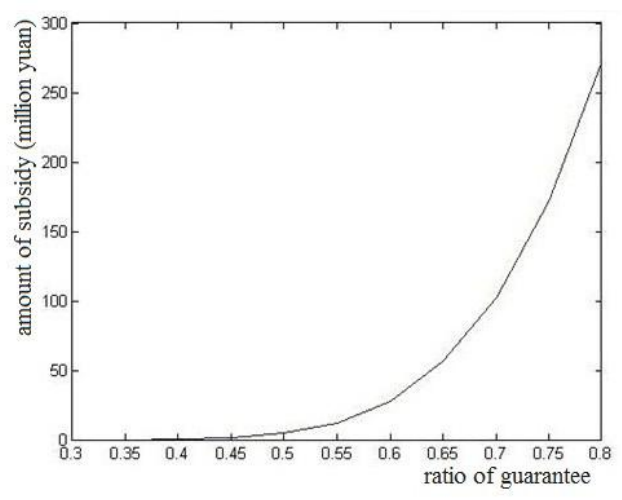

Figure 2. Sensitivity analysis of government subsidy

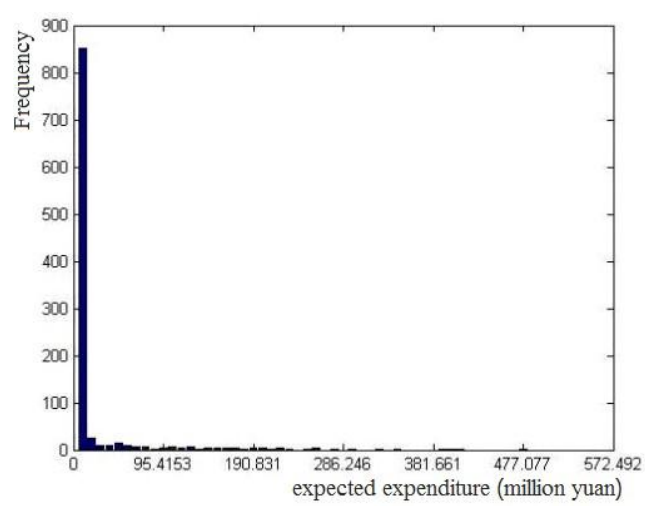

Figure 3. The expected expenditure of government under bilateral

$$
\text { government guarantee }
$$

ratio and government restrictions on competition ratio changes, the government revenue will change correspondingly (see Table 7.).

As is shown in Fig. 6, under the restricting competition,the relationship is simulated on MATLAB platform between the three factors, including restricting proportion, and the proportion of shared government income. It can be seen that the government guarantees or incomes increase with the rise of shared percentage, while these decrease with the increase of the competition restriction ratio. In practice, the government and investors can negotiate the percentage of shared and restrictedcompetition according to their strengths. This depends on the project environment and their attitudes to risk. 


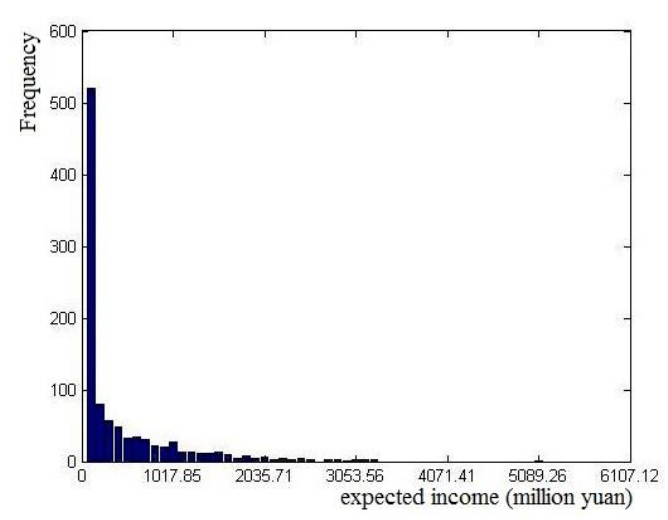

Figure 4. The expected income of government under bilateral government guarantee

TABLE VI. SIMULATION RESULT SOF GOVERNMENT REVENUE(SUBSIDY) UNDER BILITERAL SECURITY

\begin{tabular}{|c|c|c|c|}
\hline Statistics & Simulation Times & Mean & $\begin{array}{c}\text { Standard } \\
\text { Deviation }\end{array}$ \\
\hline Numerical & 1000 & 507.37 & 14075.72 \\
\hline
\end{tabular}

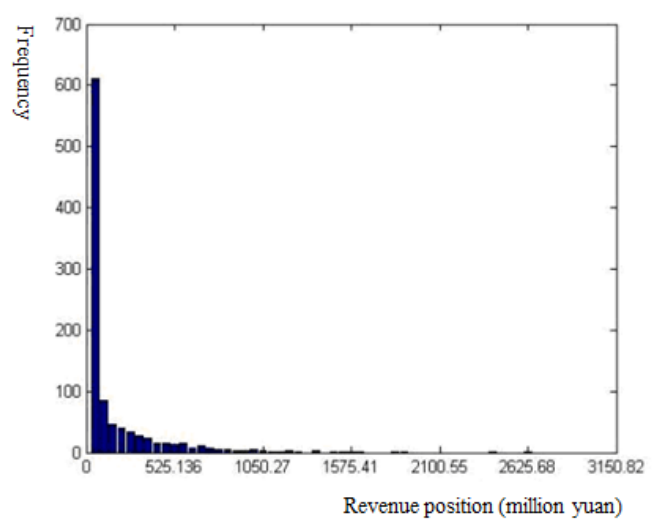

Figure 5. Government revenue under restricted competition

TABLE VII. SIMULATION RESULT SOF GOVERNMENT REVENUE UNDER REST RICTED COMPETITION

\begin{tabular}{|c|c|c|c|}
\hline Statistics & $\begin{array}{c}\text { Simulation } \\
\text { Times }\end{array}$ & Mean & $\begin{array}{c}\text { Standard } \\
\text { De viation }\end{array}$ \\
\hline Numerical & 1000 & 928.81 & 61579 \\
\hline
\end{tabular}

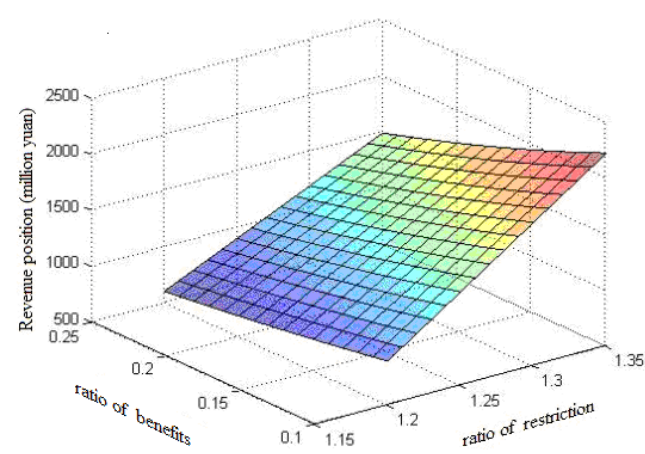

Figure 6. The relationship of income pumping proportion with the restricted competition proportion

\section{CONCLUSIONS}

The topic of the real options method investment is on the forefront of academic research in the field of decision-making in infrastructure project. Theorists on the real options approach is discussed more, but less is discussed regarding the enterprise application level. Regarding the options value of the civilian airport infrastructure, we think that government guarantee of the civilian airport industry add to the project option value. The author has used MATLAB simulation and calculated the Hongqiao business jet base case to prove option pricing in the enterprise and the impact of government guarantee on the project value by mathematical model and online simulation.

\section{References}

[1] Hayes, Robert H. Garvin, David A., "Managing as Tomorrow Mattered", Harvard Business Review, vol.10, pp.71-79, April 1982

[2] Hodder, James E., Riggs Henry E., "Pitfalls in Evaluating Risky Project", Harvard Business Review,vol.9, pp.128-135, March 1985

[3] Graham, John R., Harvey, Campbell R., "The Theory Practice of Corporate Finance: Evidence from the field", Journal of Financial Economics, vol.8, pp.187-243, September 1997

[4] Capozza, Dennis R., Li Yuming, "The Intensity Timing of Investment: the Case of Land", American Economic Review, vol.7, pp.169-186, May 1994

[5] Zhang Xue-qing,"Critical Success Factors for Public - Private Partnerships in Infrastructure", Journal of Construction engineering and Management, vol. 8, pp. 3- 14, October 2005

[6] Irwin T, Klein M, Perry G E, et al,"Managing government exposure to private infrastructure risks", World Bank Research Observer, vol. 14,pp. 229-241, October 1999

[7] LantoG.,"Managing government guarantees and contingent" Philippine Institute for Development Studies, vol.17,pp. 1-10, January 2010

[8] Merton R C, "An analytic derivation of the cost insurance and loan guarantee: an application of modern option pricing theory", Journal of Banking and Finance, vol. 1, pp. 3-11, March 1977

[9] Jones E P, Mason S P,"Valuation of loan guarantee" Journal of Banking and Finance, vol 4,pp. 89-107, March 2010. 